\title{
Article \\ Exploring Health Outcomes for U.S. Veterans Compared to Non-Veterans from 2003 to 2019
}

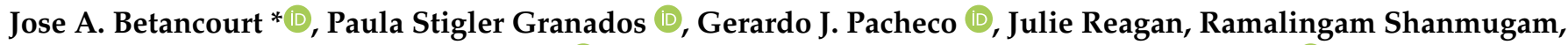 \\ Joseph B. Topinka, Bradley M. Beauvais $\mathbb{D}$, Zo H. Ramamonjiarivelo and Lawrence V. Fulton (D)
}

Citation: Betancourt, J.A.; Granados, P.S.; Pacheco, G.J.; Reagan, J.; Shanmugam, R.; Topinka, J.B.; Beauvais, B.M.; Ramamonjiarivelo, Z.H.; Fulton, L.V. Exploring Health Outcomes for U.S. Veterans Compared to Non-Veterans from 2003 to 2019. Healthcare 2021, 9, 604. https://doi.org/10.3390/ healthcare 9050604

Academic Editors: Pedram Sendi and Phyo Kyaw Myint

Received: 5 March 2021

Accepted: 6 May 2021

Published: 18 May 2021

Publisher's Note: MDPI stays neutral with regard to jurisdictional claims in published maps and institutional affiliations.

Copyright: (c) 2021 by the authors. Licensee MDPI, Basel, Switzerland. This article is an open access article distributed under the terms and conditions of the Creative Commons Attribution (CC BY) license (https:/ / creativecommons.org/licenses/by/ $4.0 /)$.
School of Health Administration, Texas State University, San Marcos, TX 78666-4684, USA; psgranados@txstate.edu (P.S.G.); gjp46@txstate.edu (G.J.P.); jkr73@txstate.edu (J.R.); shanmugam@txstate.edu (R.S.); josephtopinka@txstate.edu (J.B.T.); bmb230@txstate.edu (B.M.B.); zhr3@txstate.edu (Z.H.R.); lf25@txstate.edu (L.V.F.)

* Correspondence: jose.a.betancourt@txstate.edu; Tel.: +1-210-355-2119

Abstract: The physical demands on U.S. service members have increased significantly over the past several decades as the number of military operations requiring overseas deployment have expanded in frequency, duration, and intensity. These elevated demands from military operations placed upon a small subset of the population may be resulting in a group of individuals more at-risk for a variety of debilitating health conditions. To better understand how the U.S Veterans health outcomes compared to non-Veterans, this study utilized the U.S. Centers for Disease Control and Prevention (CDC) Behavioral Risk Factor Surveillance System (BRFSS) dataset to examine 10 different self-reported morbidities. Yearly age-adjusted, population estimates from 2003 to 2019 were used for Veteran vs. non-Veteran. Complex weights were used to evaluate the panel series for each morbidity overweight/obesity, heart disease, stroke, skin cancer, cancer, COPD, arthritis, mental health, kidney disease, and diabetes. General linear models (GLM's) were created using 2019 data only to investigate any possible explanatory variables associated with these morbidities. The time series analysis showed that Veterans have disproportionately higher self-reported rates of each morbidity with the exception of mental health issues and heart disease. The GLM showed that when taking into account all the variables, Veterans disproportionately self-reported a higher amount of every morbidity with the exception of mental health. These data present an overall poor state of the health of the average U.S. Veteran. Our study findings suggest that when taken as a whole, these morbidities among Veterans could prompt the U.S. Department of Veteran Affairs (VA) to help develop more effective health interventions aimed at improving the overall health of the Veterans.

Keywords: U.S. Veteran; deployment; spatial regression; obesity; comorbidities; risk-factors; overweight; diabetes

\section{Introduction}

The collective health of those who served in the U.S. military exhibits a number of health conditions that paint a concerning picture of morbidity among the U.S. Veteran population [1-5]. Veterans are not only found to suffer from obesity at higher levels when compared to the average U.S. population [6,7], but also suffer from a significantly higher level of associated co-morbidities including coronary heart disease-CHD or angina; stroke; skin cancer; other cancers; chronic obstructive pulmonary disease (COPD), emphysema, or chronic bronchitis; arthritis, rheumatoid arthritis, gout, lupus, or fibromyalgia; depressive disorders; and diabetes [1,8-10]. Particularly concerning is the interaction of depression, diabetes, and obesity and their associated health outcomes $[6,11,12]$. Coupled with the growing 'obesity epidemic' impacting the U.S., it is important to identify geographic locations where Veteran populations reside so as to better resource health intervention programs aiming to meet the health needs of Veterans [13-15]. By analyzing populationbased, health data for Veterans when compared to the U.S. population, this may better 
identify the population of U.S. military Veterans (by specific demographic characteristics) who could benefit from health systems interventions aimed at solutions for reducing weight and reducing morbidity from certain health risks [1,15].

\subsection{Stressors Associated with Military Service and Deployments}

Military service is associated with a number of physical and psychological stressors including "deploying to overseas missions, participating in combat operations, sustaining trauma and/or serious physical and/or mental injuries, and ultimately reintegrating back into civilian life" [6,16]. These stressors may have immediate negative effects such as physical or psychological injury and/or trauma, or delayed effects that do not manifest until later in life [16]. Additional stressors do not necessarily involve deployments nor combat, but simply maintaining requisite levels of physical fitness and height/weight standards in accordance with military service standards [17]. Every Active-duty Service member (ADSM) is required to meet strict height and weight standards which are evaluated every six months in order to remain employed. This is normally not a challenge to Service members who regularly exercise with their units and maintain healthy eating habits. However, those individuals who do not exercise nor practice good eating habits on a regular basis may find themselves close to exceeding their weight limits at the time of their fitness test. In order to "make weight" or meet weight standards, a number of Service members resort to unhealthy behaviors including excessive exercise, fasting/skipping meals, using sauna/rubber suits, laxatives, diuretics, and in extreme cases, inducing vomiting [17]. Researchers have found that these unhealthy behaviors often result in maladaptive eating behaviors later in life including binge eating, vomiting, emotional eating, food addiction, and night eating: all contributors to obesity [17].

\subsection{Operational Tempo (OPTEMPO)/Personnel Tempo (PERSTEMPO)}

Each year, the U.S. Congress determines the number of personnel assigned to the U.S. Department of Defense (DoD) as required by law. Figure 1 depicts the number of Active-duty personnel by Service (Army, Navy, Marine Corps, and Air Force) from 1950 through the year 2000 [18]. Figure 1 illustrates sharp increases in total personnel strength levels in times of conflict such as during the Korean War and Vietnam Conflict. More personnel available for deployment normally allows for the average Service member to be deployed only one time during their total military experience. However, with the advent of the all-volunteer force in the early 1970s [19], the total number of military personnel available for deployment began a steady decline in total size, which as depicted in Figure 1 continues to the present day.

Unfortunately, the pace of military operations (Operational Tempo or OPTEMPO) has not aligned well with this reduction in the size of the force. Figure 2 not only depicts the major military conflicts from 1940 (World War II) through the present, but also the duration of each conflict, which when compared to the previous figure (Figure 1) may suggest that with a reduced pool of deployable personnel, the average Service member will likely deploy MORE than one time during their military experience [20].

Figure 3 further specifically focuses on the period 1980 through the present (2020) and illustrates a sharp increase in the number of military operations at a time when there have been a smaller number of available Service members, resulting in an increased personnel tempo (PERSTEMPO). 


\begin{tabular}{|c|c|c|c|c|c|c|c|c|}
\hline \multicolumn{8}{|c|}{$\begin{array}{c}\text { Historical Number of DoD Active-Duty Military Personnel Strength } \\
\text { Levels for Fiscal Years } 1950-2020^{*}\end{array}$} & \\
\hline Year & $\begin{array}{l}\text { Total Active Duty } \\
\text { Force }\end{array}$ & Year & $\begin{array}{l}\text { Total Active Duty } \\
\text { Force }\end{array}$ & Year & $\begin{array}{l}\text { Total Active Duty } \\
\text { Force }\end{array}$ & Year & $\begin{array}{l}\text { Total Active Duty } \\
\text { Force }\end{array}$ & \\
\hline 1950 & $1,459,462$ & 1970 & $3,064,760$ & 1990 & $2,043,705$ & 2010 & $1,430,552$ & \\
\hline 1951 & $3,249,371$ & 1971 & $2,713,044$ & 1991 & $1,985,555$ & 2011 & $1,424,317$ & \\
\hline 1952 & $3,635,912$ & 1972 & $2,321,959$ & 1992 & $1,807,177$ & 2012 & $1,400,535$ & \\
\hline 1953 & $3,555,067$ & 1973 & $2,251,936$ & 1993 & $1,705,103$ & 2013 & $1,382,684$ & \\
\hline 1954 & $3,302,104$ & 1974 & $2,162,005$ & 1994 & $1,610,490$ & 2014 & $1,338,487$ & \\
\hline 1955 & $2,935,107$ & 1975 & $2,128,120$ & 1995 & $1,518,224$ & 2015 & $1,313,940$ & \\
\hline 1956 & $2,806,441$ & 1976 & $2,081,910$ & 1996 & $1,471,722$ & 2016 & $1,301,308$ & \\
\hline 1957 & $2,794,761$ & 1977 & $2,074,543$ & 1997 & $1,438,562$ & 2017 & $1,335,122$ & \\
\hline 1958 & $2,599,518$ & 1978 & $2,061,708$ & 1998 & $1,406,830$ & 2018 & $1,304,032$ & \\
\hline 1959 & $2,503,631$ & 1979 & $2,026,892$ & 1999 & $1,385,703$ & 2019 & $1,318,499$ & \\
\hline 1960 & $2,475,438$ & 1980 & $2,050,627$ & 2000 & $1,384,338$ & 2020 & $1,289,372$ & \\
\hline 1961 & $2,482,905$ & 1981 & $2,082,560$ & 2001 & $1,400,379$ & & & \\
\hline 1962 & $2,805,603$ & 1982 & $2,108,612$ & 2002 & $1,420,620$ & & & \\
\hline 1963 & $2,698,927$ & 1983 & $2,123,349$ & 2003 & $1,437,450$ & & & \\
\hline 1964 & $2,685,782$ & 1984 & $2,138,157$ & 2004 & $1,424,787$ & & & \\
\hline 1965 & $2,653,926$ & 1985 & $2,151,032$ & 2005 & $1,386,407$ & & & \\
\hline 1966 & $3,092,175$ & 1986 & $2,169,112$ & 2006 & $1,385,870$ & & & \\
\hline 1967 & $3,375,485$ & 1987 & $2,174,217$ & 2007 & $1,378,769$ & & & \\
\hline 1968 & $3,546,071$ & 1988 & $2,138,213$ & 2008 & $1,401,079$ & & & \\
\hline 1969 & $3,458,072$ & 1989 & $2,130,229$ & 2009 & $1,418,813$ & & & \\
\hline & & & & & & formatic & $\begin{array}{l}\text { Manpower Data Ce } \\
\text { lysis Division (FYo }\end{array}$ & $\begin{array}{l}\text { DMDC) } \\
\text { al Report) }\end{array}$ \\
\hline
\end{tabular}

Figure 1. Total Personnel levels for U.S. Department of Defense (DoD) military personnel from 1950 through present (US Defense Manpower Data Center (DMDC)).

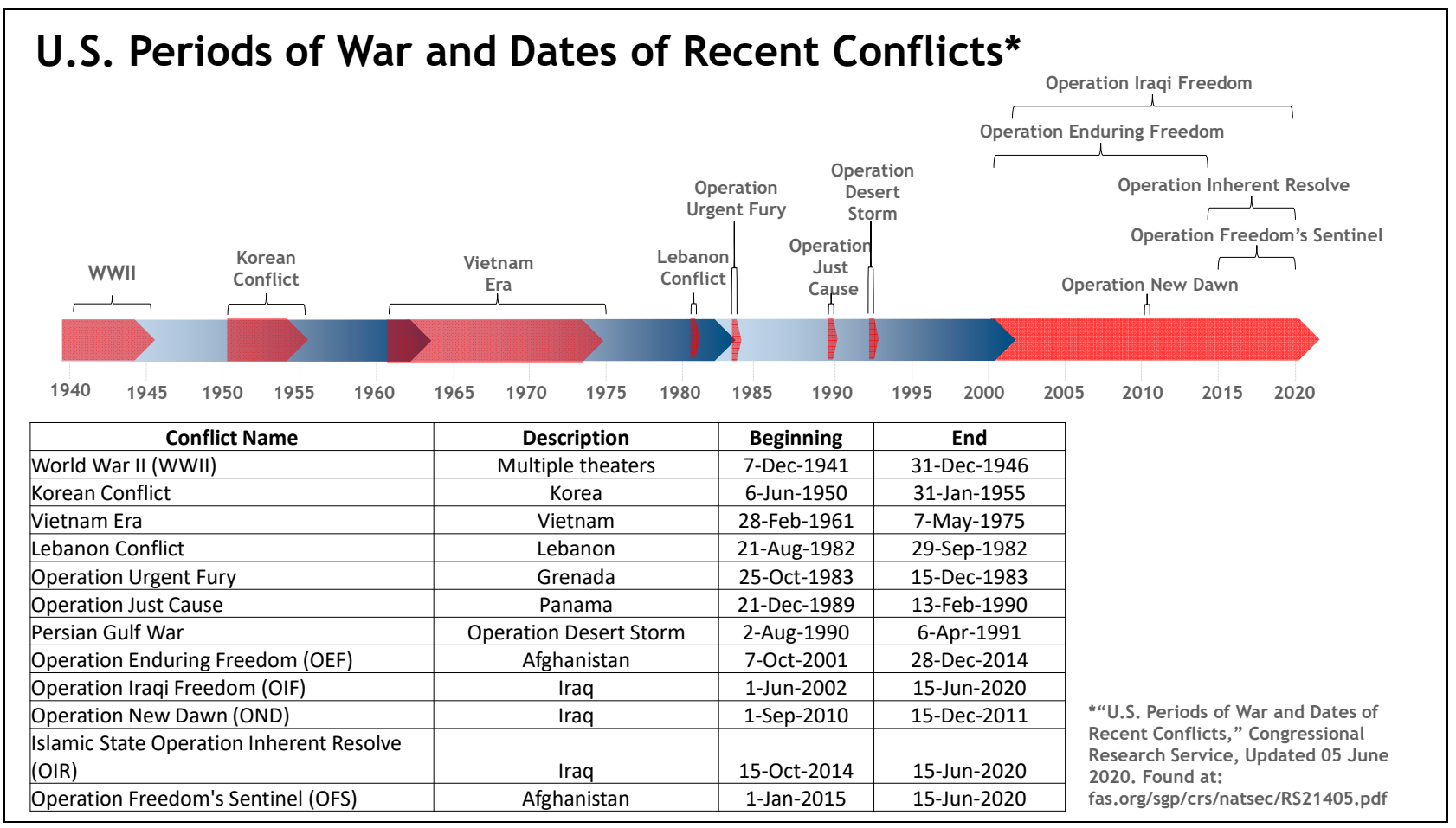

Figure 2. U.S. Periods of war and dates of recent conflicts from 1940 through present. 


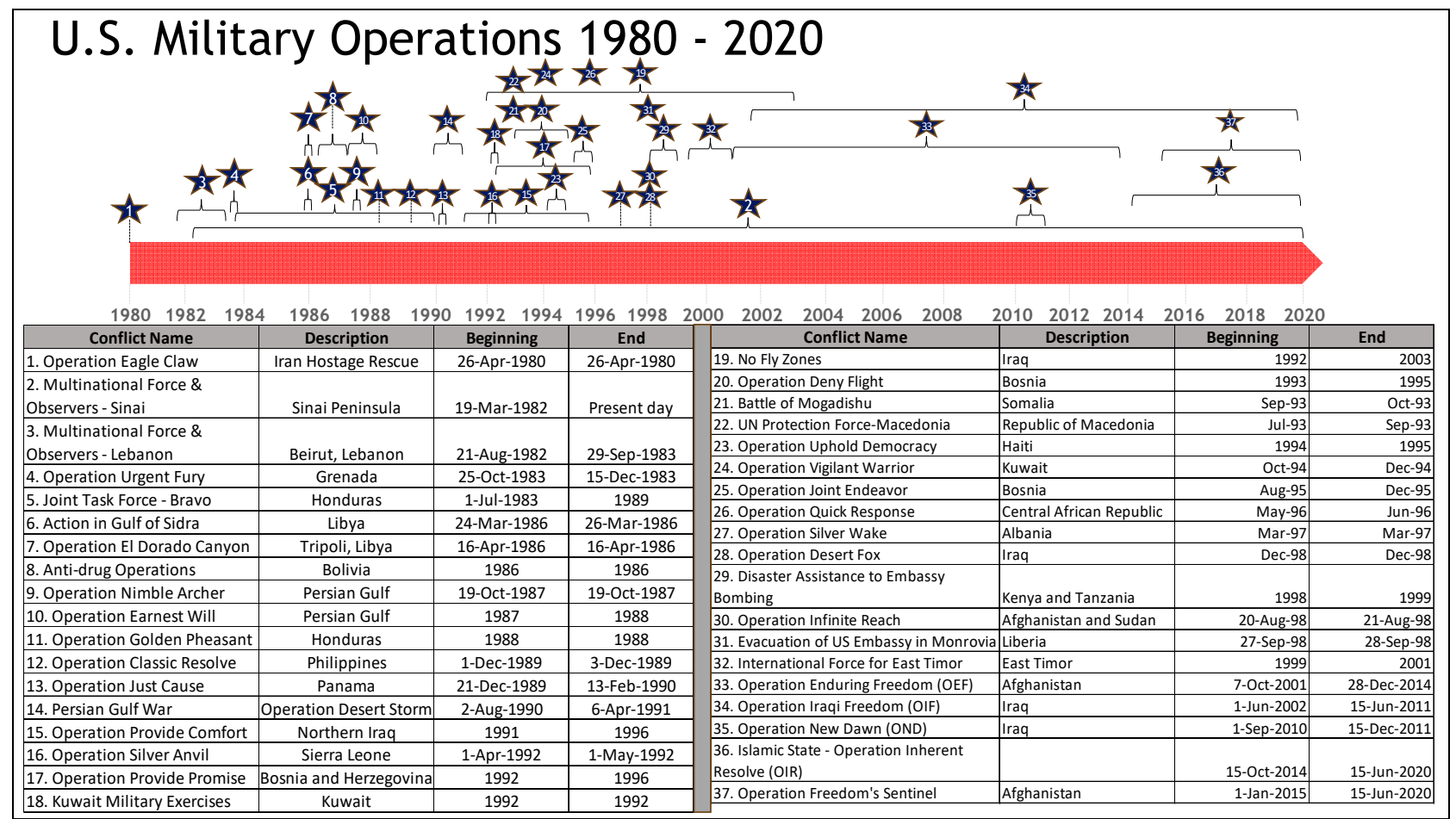

Figure 3. U.S. military operations from 1980 through present.

As depicted in Figures 2 and 3, the number, length, and duration of military operations since the mid to late 1980s through the present has intensified, while the size of the U.S. military has gradually declined throughout this period. This combination of increased demand in military operations placed on a reduced supply of available and deployable personnel has resulted in a military force that is exhibiting the results of these stressors in poor health outcomes [1]. The U.S. DoD has attempted to increase the available pool of personnel for military deployments by utilizing additional military units from the Reserve Component (RC) as well as the National Guard [20]. However, some prior research indicates this only increased the number of Veterans with poor health outcomes [1]. The specific aim of this study is to provide a snapshot or a "glimpse" into potential associations between the stressors associated with multiple deployments, and poor health outcomes among US Veterans. We specifically investigate morbidities between Veteran and non-Veterans and over time with the belief that Veterans are likely to experience more morbidities due to the difficulties and exposures of military service. Further, we use data from 2003 to 2010 and aggregated data from 2011 to 2019, which include the newest release of the Centers for Disease Control and Prevention (CDC) Behavioral Risk Factor Surveillance System (BRFSS) [21-23] dataset, to look at demographic, socio-economic, geographic, time, and Veteran status variables that may assist in explaining any differences.

\section{Materials and Methods}

To compare Veteran and non-Veteran health outcomes, yearly age-adjusted, population estimates from 2003 (or earliest year available) to 2019 were used for Veteran/nonVeteran. Sampling weights were applied to evaluate the panel series for each of the separate morbidities (overweight/obesity, heart disease, stroke, skin cancer, cancer, COPD, arthritis, mental health issues, kidney disease, and diabetes). Confidence intervals were graphically constructed. General linear models (GLM's) with quasi-binomial link functions, which account for fractional observations due to weighting, were then created by morbidity from the year 2011 forward. Because of the change in BRFSS sampling methods beginning in 2011, the CDC warns that "The BRFSS 2011 data should be considered a baseline year for data analysis and is not directly comparable to previous years of BRFSS data because 
of the changes in weighting methodology and the addition of the cell phone sampling frame [24]."

\subsection{Data Source}

The BRFSS is a continuous health survey system that collects information from each state in the U.S., three U.S. territories and the District of Columbia about modifiable risk factors for chronic diseases and other leading causes of death [25]. The BRFSS is conducted by state health departments annually with assistance from the CDC using inhouse interviewers or contracts with telephone call centers or universities [25-27]. There is a standardized core questionnaire with optional modules, and some states add in their own questions. The survey uses Random Digit Dialing (RDD) techniques on both landlines and cell phones to conduct the interviews. An estimated 400,000 surveys are conducted annually [26]. A full description of the methodology can be found online [28]. The BRFSS is a publicly available, anonymous data set that does not require an institutional review board approval or an exempt status for its use.

\subsection{Study Sample}

For this study, BRFSS data from 2003 to 2019 (last available year) were acquired from the CDC [26]. Each year was used to estimate the population point estimate for the specific time and morbidity. The BRFSS data are considered by the CDC to be the nation's best source for health-related survey data, and the 2019 version includes 418,268 observations. Applying stratum and individual weights to these observations results in a picture of the entire nation's self-reported health [29]. In total, this study included 7.181 million sample observations.

Table 1 shows the population estimates and sample sizes for each of the years in question by Veteran/Non-Veteran status. Sampling weights based on location and sociodemographic information were applied to estimate the entire US population, resulting in fractional values for population estimates. Prior to 2011, samples were weighted by stratum (area code/prefix combinations) times the inverse number of telephones in the household times the number of adults in the household times the number of people in an age-by-sex or age-by-race/ethnicity-by-sex category. This was done in the population of a region or a state divided by the sum of the preceding weights for the respondents in the same age-by-sex or age-by-race/ethnicity-by-sex category (adjusting for noncoverage and nonresponse and forces the sum of the weighted frequencies to equal population estimates for the region or state.) There were two separate variable weight fields. This weighting was applied through the use of separate fields for stratum and weights. From 2011 onwards, raking replaced the post-stratification process. Raking allows for incorporation of cellular telephone survey data and allows for inclusion of other demographic considerations to improve socio-demographic matching by stratum.

\subsection{Study Measures}

Table 2 provides the variable names, question, and coding for dependent variables, controls, the primary independent variable, and the weighting variables. Over the course of two decades, several variable name and measurement changes occurred. Most were either nominal (e.g., Veteran status) or easily re-codable. A complete discussion of these recoded variables is available online [30]. One additional variable was included for longitudinal models. This variable, "YEAR" was an indicator for the year of the BRFSS. 
Table 1. Population estimates and sample sizes by year and Veteran status.

\begin{tabular}{ccccccc}
\hline Year & $\begin{array}{c}\text { Non-Vet } \\
\text { Population }\end{array}$ & $\begin{array}{c}\text { Vet Popu- } \\
\text { lation }\end{array}$ & $\begin{array}{c}\text { Population } \\
\text { Estimate }\end{array}$ & $\begin{array}{c}\text { Non-Vet } \\
\text { Sample }\end{array}$ & $\begin{array}{c}\text { Vet } \\
\text { Sample }\end{array}$ & $\begin{array}{c}\text { Total } \\
\text { Sample }\end{array}$ \\
\hline 2003 & $190,348,049$ & $30,003,072$ & $220,351,121$ & 228,159 & 36,525 & 264,684 \\
2004 & $191,637,278$ & $29,746,086$ & $441,734,485$ & 260,982 & 42,840 & 303,822 \\
2005 & $194,578,583$ & $29,532,523$ & $445,494,470$ & 305,107 & 51,005 & 356,112 \\
2006 & $198,138,945$ & $29,118,914$ & $451,368,965$ & 304,989 & 50,721 & 355,710 \\
2007 & $202,498,717$ & $27,673,461$ & $457,430,037$ & 370,990 & 59,922 & 430,912 \\
2008 & $205,615,985$ & $27,244,684$ & $463,032,847$ & 358,433 & 56,076 & 414,509 \\
2009 & $208,756,506$ & $26,249,349$ & $467,866,524$ & 374,909 & 57,698 & 432,607 \\
2010 & $211,037,577$ & $26,048,662$ & $472,092,094$ & 390,643 & 60,432 & 451,075 \\
2011 & $212,198,501$ & $25,812,791$ & $475,097,531$ & 441,873 & 64,594 & 506,467 \\
2012 & $216,959,427$ & $26,098,283$ & $481,069,002$ & 415,817 & 59,870 & 475,687 \\
2013 & $219,968,409$ & $26,056,006$ & $489,082,125$ & 430,268 & 61,505 & 491,773 \\
2014 & $220,704,167$ & $27,778,365$ & $494,506,947$ & 402,544 & 62,120 & 464,664 \\
2015 & $224,174,518$ & $27,172,620$ & $499,829,670$ & 383,614 & 57,842 & 441,456 \\
2016 & $227,144,466$ & $27,006,670$ & $505,498,274$ & 422,384 & 63,919 & 486,303 \\
2017 & $229,254,924$ & $26,398,281$ & $509,804,341$ & 392,148 & 57,868 & 450,016 \\
2018 & $230,694,063$ & $27,379,324$ & $513,726,592$ & 381,382 & 56,054 & 437,436 \\
2019 & $226,740,688$ & $25,689,603$ & $510,503,678$ & 365,038 & 53,230 & 418,268 \\
\hline Totals & $3,610,450,803$ & $465,008,694$ & $7,898,488,703$ & $6,229,280$ & 952,221 & $7,181,501$ \\
\hline
\end{tabular}

Table 2. Variables in the Study.

\begin{tabular}{|c|c|c|}
\hline Type & Name & \\
\hline Dependent Variable: Overweight/Obese & _RFBMI5 & $\begin{array}{l}\text { Adults who have a body mass index greater than } \\
\text { 25.00. No, Yes, Don't Know / Refused/Missing }\end{array}$ \\
\hline $\begin{array}{l}\text { Dependent Variable: Angina or coronary } \\
\text { heart disease }\end{array}$ & CVDCRHD\# & $\begin{array}{c}\text { (Ever told) you had angina or coronary heart } \\
\text { disease? Yes, No, Don't Know /Not Sure, Not } \\
\text { Asked/Missing }\end{array}$ \\
\hline Dependent Variable: Stroke & CVDSTRK\# & $\begin{array}{l}\text { (Ever told) you had a stroke. Yes, No, Don't } \\
\text { Know/Not Sure, Not Asked/Missing }\end{array}$ \\
\hline Dependent Variable: Skin cancer & CHCSNCR & $\begin{array}{l}\text { (Ever told) you had skin cancer? Yes, No, Don't } \\
\text { Know / Not Sure, Not Asked/Missing } \\
\text { (Ever told) you had any other types of cancer? }\end{array}$ \\
\hline Dependent Variable: Other cancer & CHCOCNCR & $\begin{array}{c}\text { Yes, No, Don't Know/Not Sure, Not } \\
\text { Asked/Missing }\end{array}$ \\
\hline Dependent Variable: COPD & CHCCOPD\# & $\begin{array}{l}\text { (Ever told) (you had) C.O.P.D., emphysema or } \\
\text { chronic bronchitis? Yes, No, Don't Know / Not } \\
\text { Sure, Not Asked/Missing }\end{array}$ \\
\hline Dependent Variable: Arthritis & HAVARTH\# & $\begin{array}{l}\text { Ever told) (you had) some form of arthritis, } \\
\text { rheumatoid arthritis, gout, lupus, or } \\
\text { fibromyalgia? Yes, No, Don't Know / Not Sure, } \\
\text { Not Asked/Missing }\end{array}$ \\
\hline Dependent Variable: Mental Health & MENTHLTH & $\begin{array}{c}\text { Now thinking about your mental health, which } \\
\text { includes stress, depression, and problems with } \\
\text { emotions, for how many days during the past } 30 \\
\text { days was your mental health not good? Number } \\
\text { of Days, None, Don't Know / Not Sure, Refused, } \\
\text { Not Asked/Missing }\end{array}$ \\
\hline Dependent Variable: Kidney Disease & CHCKDNY & $\begin{array}{c}\text { Not including kidney stones, bladder infection or } \\
\text { incontinence, were you ever told you had kidney } \\
\text { disease? Yes, No, Don't Know / Not Sure, Not } \\
\text { Asked/Missing }\end{array}$ \\
\hline
\end{tabular}


Table 2. Cont.

\begin{tabular}{|c|c|c|}
\hline Type & Name & \\
\hline Dependent Variable: Diabetes & DIABETE\# & $\begin{array}{l}\text { (Ever told) (you had) diabetes? Yes, Yes } \\
\text { Gestational Only, No, No Pre-Diabetes, Don't } \\
\text { Know/Not Sure, Refused, Not Asked/Missing } \\
\text { (Recoded to Yes Non-Gestational, No, Unknown) }\end{array}$ \\
\hline Demographic Control: Age & _AGE_G & $\begin{array}{c}\text { Six-level imputed age category: } 18-24,25-34 \\
\text { 35-44, } 45-54,55-64,65+ \\
\text { Imputed race/ethnicity value: White }\end{array}$ \\
\hline Demographic Control: Race & _IMPRACE & $\begin{array}{c}\text { Non-Hispanic, Black Non-Hispanic, Asian } \\
\text { Non-Hispanic, American Indian/Alaska Native } \\
\text { Non-Hispanic, Hispanic, Other Race } \\
\text { Non-Hispanic }\end{array}$ \\
\hline Demographic Control: Gender & SEX & $\begin{array}{c}\text { Calculated sex variable: Birth Sex Male, Birth } \\
\text { Sex Female }\end{array}$ \\
\hline Demographic Control: Marital Status & MARITAL & $\begin{array}{c}\text { Are you: Married, Divorced, Widowed, } \\
\text { Separated, Never Married, Unmarried Couple, } \\
\text { Refused, Not Asked/Missing }\end{array}$ \\
\hline Socioeconomic Control: Income & INCOME\# & $\begin{array}{c}\text { Is your annual household income from all } \\
\text { sources: }<\$ 10 \mathrm{~K},<\$ 15 \mathrm{~K},<\$ 20 \mathrm{~K},<\$ 25 \mathrm{~K},<\$ 35 \mathrm{~K} \text {, } \\
<\$ 50 \mathrm{~K},<\$ 75 \mathrm{~K}, \$ 75 \mathrm{~K}+\text {, Don't Know / Not Sure, } \\
\text { Refused, Not Asked/Missing }\end{array}$ \\
\hline Socioeconomic Control: Education & EDUCA & $\begin{array}{c}\text { Level of education completed: < High School, } \\
\text { Graduated High School, Attended } \\
\text { College/Technical School, Graduated } \\
\text { College/Technical School, Don't Know /Not } \\
\text { Sure/Missing }\end{array}$ \\
\hline Socioeconomic Control: Employment & EMPLOY\# & $\begin{array}{l}\text { Are you currently ... ? Employed for Wages, } \\
\text { Self-Employed, Out of Work } 1+\text { Years, Out of } \\
\text { Work <1 Year, A Homemaker, A Student, Retired, } \\
\text { Unable to Work, Refused, Not Asked/Missing }\end{array}$ \\
\hline Geographical control: State & _STATE & $\begin{array}{l}\text { Federal Information Processing Standard Code } \\
\text { for State }\end{array}$ \\
\hline Independent Variable: Veteran Status & VETERAN\# & $\begin{array}{c}\text { Have you ever served on active duty in the } \\
\text { United States Armed Forces, either in the regular } \\
\text { military or in a National Guard or military } \\
\text { reserve unit? }\end{array}$ \\
\hline Weighting Variable & _STSTR & Sample Design Stratification Variable \\
\hline Weighting Variable & _LLCPWT & Final weight assigned to each respondent \\
\hline
\end{tabular}

\subsubsection{Dependent Variables}

All dependent variables in the study were dichotomously coded. In all cases, the categories of "Don't Know/Not Sure" and "Not Asked/Missing" were imputed with the modal response, as the proportion of these values was $1 \%$ or less. For obesity, the modal response was greater than $25 \%$ body mass index. For all other dependent variables, the modal response was "No." For all variables other than obesity, the proportion missing was $1 \%$ or less (negligible). For obesity, about $10 \%$ of the observations were in the categories "Don't Know/Refused/Missing." The modal response reflecting overweight/obesity status (greater than $60 \%$ of the respondents) is likely to best categorize these individuals. Table 3 shows the unweighted and weighted proportions in the categories of "Yes", "No", and "Unknown" for the dependent variables in year 2019.

The mental health variable was unique in that there was not a specific variable that addressed the presence or absence of the disease. Instead, the question in the BRFSS survey was, "Now thinking about your mental health, which includes stress, depression, and problems with emotions, for how many days during the past 30 days was your mental health not good?" This is the MENTHLTH variable in the BRFSS dataset. To address this issue, we dichotomously coded mental health as " 1 " if there were any days in the past 30 days that an individual reported his or her mental health status as "not good." Many of the 
dependent variables did not have observations dating back to 2003 (or had inconsistent add-on modules not universally asked of respondents). Table 4 shows the analysis starting year for each of the variables.

Table 3. Year 2019 dependent variable proportions are shown (sample/population estimate).

\begin{tabular}{llll}
\hline Question * & Yes & No & Unknown \\
\hline Overweight/Obese & $62 \% / 60 \%$ & $29 \% / 30 \%$ & $9 \% / 10 \%{ }^{+}$ \\
Coronary Heart & $6 \% / 4 \%$ & $93 \% / 95 \%$ & $1 \% / 1 \%$ \\
Disease & $4 \% / 3 \%$ & $95 \% / 96 \%$ & $1 \% / 1 \%$ \\
Stroke & $10 \% / 6 \%$ & $90 \% / 93 \%$ & $0 \% / 0 \%$ \\
Skin Cancer & $10 \% / 7 \%$ & $90 \% / 93 \%$ & $0 \% / 0 \%$ \\
Other Cancer & $8 \% / 7 \%$ & $91 \% / 93 \%$ & $1 \% / 0 \%$ \\
COPD & $33 \% / 25 \%$ & $66 \% / 75 \%$ & $1 \% / 0 \%$ \\
Arthritis & $34 \% / 37 \%$ & $66 \% / 63 \%$ & $0 \% / 0 \%$ \\
Mental Health & $4 \% / 3 \%$ & $96 \% / 97 \%$ & $0 \% / 0 \%$ \\
Kidney Issues & $14 \% / 11 \%$ & $86 \% / 89 \%$ & $0 \% / 0 \%$ \\
Diabetes & &
\end{tabular}

${ }^{*}$ May not add to $100 \%$ due to rounding, ${ }^{+}$maximum missing of any year/variable.

Table 4. Starting years for analysis.

\begin{tabular}{ll}
\hline Variable & Year \\
\hline Overweight/Obese & 2003 \\
Heart Disease & 2005 \\
Stroke & 2005 \\
Skin Cancer & 2011 \\
Cancer & 2011 \\
COPD & 2011 \\
Arthritis & 2011 \\
Mental Health & 2003 \\
Kidney Disease & 2011 \\
Diabetes & 2003 \\
\hline
\end{tabular}

\subsubsection{Independent Variable}

The primary variables of interest were the year of the estimate (2003 through 2019), and Veteran status, recoded $\{0=$ did not self-report as Veteran, $1=$ self-reported as veteran $\}$. This coding results from the survey questions that follow.

- Years 2003 through 2006 (Code: VETERAN). Have you ever served on active duty in the United States Armed Forces, either in the regular military or in a National Guard or military reserve unit?" $1=$ Yes, $2=$ No, 7 = Don't Know $/$ Not Sure, $9=$ Refused, Blank $=$ Not asked $/$ Missing.

- Years 2007 through 2008 (Code: VETERAN1). "Have you ever served on active duty in the United States Armed Forces, either in the regular military or in a National Guard or military reserve unit? Active duty does not include training for the Reserves or National Guard, but DOES include activation, for example, for the Persian Gulf War." $1=$ Yes, $2=$ No, 7 = Don't Know $/$ Not Sure, $9=$ Refused, Blank $=$ Not asked $/$ Missing.

- Years 2009 (Code VETERAN2). "Have you ever served on active duty in the United States Armed Forces, either in the regular military or in a National Guard or military reserve unit? Active duty does not include training for the Reserves or National Guard, but DOES include activation, for example, for the Persian Gulf War." 1 = Yes, now on Active Duty, 2 = Yes, on Active Duty during the last 12 months but not now, 3 $=$ Yes, on active duty in the past, but not during the last 12 months, $4=$ No, training for Reserves or National Guard only, $5=$ No, never served in the military, $7=$ Don't Know $/$ Not Sure, $9=$ Refused, Blank $=$ Not asked $/$ Missing. 
- Years 2010 through 2019 (Code: VETERAN3). "Have you ever served on active duty in the United States Armed Forces, either in the regular military or in a National Guard or military reserve unit? Active duty does not include training for the Reserves or National Guard, but DOES include activation, for example, for the Persian Gulf War." $1=$ Yes, 2 = No, 7 = Don't Know /Not Sure, 9 = Refused, Blank = Not asked $/$ Missing.

In all years, the responses were identically coded with the exception of 2009. Recoding for this year assigned any yes values equal to 1 and all other values equal to zero. Due to the exceedingly low numbers of responses that were blank, refused, and "do not know" (e.g., $0.574 \%$ in 2019$)$, these were imputed with the modal response of non-Veteran $(86.7 \%$ of the population in 2019).

\subsubsection{Covariates}

Demographic Variables

Gender was dichotomously recoded ( $1=$ self-identify as male, $0=$ otherwise). In 2019, missing data were for this variable were imputed by BRFSS; in 2018, only $0.26 \%$ of all observations were don't know/not sure or refused. The mode was imputed in these cases.

Race was coded as ( $1=$ Caucasian, $0=$ otherwise), and ethnicity was coded as ( $1=$ Hispanic, $0=$ otherwise). These variables were both generated from the IMPRACE or RACE variables, depending on the year. Completely discrete categories were readily attainable via recoding (see https://rpubs.com/R-Minator/BRFSS). Age was coded as ( $1=$ age 18 to 24,2 = age 25 to $36,3=$ age 35 to $44,4=$ age 45 to $54,5=$ age 55 to $64,6=$ age 65 or older), with the small proportion of missing (e.g., 1.6\% in 2019) recoded to the modal category (age 65 or older). Marital status was also dichotomously coded ( $1=$ married, $0=$ otherwise). Again, the small proportion missing was negligible (e.g., $0.82 \%$ in 2019).

\section{Socio-Economic Variables}

Education status was a dichotomous variable, coded as ( $1=$ self-identify as a college graduate, $0=$ otherwise). Little data were missing from this variable (less than $0.5 \%$ in 2019 ). The variable income was also dichotomous with values $(1=$ self-reported modal income of $\$ 75,000$ or more household income per year, $0=$ otherwise). Employment was also evaluated as a dichotomous variable with $(1=$ employed for wages, the modal response, and $0=$ otherwise).

\section{Geographic Variable}

The variable "region "was a feature engineered Census Bureau region based on the state/territory of residence based on the Federal Information Processing System (FIPS) Codes with (1 = New England, 2 = East North Central, 3 = East South Central, 4 = Middle Atlantic, 5 = Mountain, 6 = Pacific, 7 = South Atlantic, $8=$ West North Central, 9 = West South Central, $10=$ Territories). We collapsed the states into regions to provide better clarity of analysis. Definitions of the states in these regions are available here: https:/ / www.census.gov/prod/1/gen/95statab/preface.pdf.

\section{Time Variable}

For the combined 2011 through 2019 datasets, a variable indicating the BRFSS year was created. This variable was treated as a factor-level variable to identify non-linear temporal effects.

\subsection{Methods and Models}

\subsubsection{Descriptive Models}

Univariate age-adjusted models for Veterans and Non-Veterans were constructed for each dependent variable for each year to evaluate differences. These models were accompanied by sparkline graphs, which provide small multiples [31]. 


\subsubsection{General Linear Models}

For GLM models using the 2011-2019 data, quasibinomial models were generated. Given the dichotomous nature of the dependent variables, a logistic regression (assuming binomial family link) would have been appropriate until weights were applied. When weighted, the dichotomous variables become fractional. The quasibinomial is then appropriate for these types of weighted survey analyses [32].

\subsubsection{Data Analysis}

R Statistical Software [25-27] and R Studio [33] were used to conduct the analysis. The survey library in R [34] provided the weighting necessary to generate population estimates, and the EpiTools package [35] provided age-adjusted estimates to compare Veteran and non-Veteran populations.

\section{Results}

The entirety of the analysis is available for review online [29].

\subsection{Descriptive Statistics}

The age-adjusted comparisons for all dependent variables for all years by Veteran and non-Veteran status are shown in Table 5. For the years 2003 to 2010, unfortunately we were unable to combine these data due to differences in the weighting and data collection methods used by the CDC during this timeframe. Therefore, we examined these data independently and arrived at our best estimates. For this period, the results indicate that Veterans have higher rates for obesity, diabetes, and heart disease while stroke is relatively the same between the Veteran and non-Veteran populations. However, the Veteran population reported less mental health issues than the non-Veteran population. At the bottom of the table, the combined years for 2011 through 2019 are shown. The 2011-2019 data show that Veterans are generally more obese (72\% vs. $60 \%$ ) and have higher rates of diabetes $(19 \%$ vs. $16 \%)$, heart disease $(13 \%$ vs. $8 \%)$, stroke $(6 \%$ vs. $5 \%)$, skin cancer ( $16 \%$ vs. $11 \%)$, cancer (13\% vs. $11 \%)$, and COPD. The $2011-2019$ estimated rate of arthritis $(4 \%)$ is identical for both groups. Veterans have lower rates of mental health issues ( $30 \%$ vs. $37 \%$ ) and arthritis (nominally, $37 \%$ vs. $38 \%$ ), compared with the non-Veteran population. Trends from 2003 to 2019 for each variable are generally flat, as evidenced by the sparkline graphs and a review of the age-adjusted table values.

\subsection{General Linear Models (GLMs)}

The CDC suggests that surveys before 2011 should not be used as part of longitudinal analysis [36] due to changes in weighting. Thus, GLM models were built using only dependent variables from 2011 to 2019. A quasi-binomial link function was used, s, as it allowed fractional values of integers that occur when weights are applied [37]. These results are shown in Table 6. The GLM results depict odds ratios for all control variable groupings (demographics, socio-economics, geographical regions, and years) as well as for Veteran status and year for each of the dependent variables. Demographics and socio-economic variables account partially for socioeconomic determinants of health associated with disease processes. Geographical effects were considered as they may account for culture and other locality factors (environmental effects). Statistically significant odds ratios greater than 1 suggest a higher-than-average risk for all people within those categories (regardless of Veteran status). Veterans disproportionately self-report a statistically significant and higher amount of the 10 selected morbidities when compared to non-Veterans with only a single exception: mental health. The odds ratio for mental health is 0.972 . These findings are congruent but not identical to the age-adjusted marginal analysis. 
Table 5. Age-adjusted comparisons for all dependent variables for all years by Veteran and non-Veteran status.

\begin{tabular}{|c|c|c|c|c|c|c|c|c|c|c|c|c|c|c|c|c|c|c|c|c|}
\hline \multirow[b]{2}{*}{ Year * } & \multicolumn{2}{|c|}{ Obesity } & \multicolumn{2}{|c|}{ Diabetes } & \multicolumn{2}{|c|}{ Mental Health } & \multicolumn{2}{|c|}{ Heart Disease } & \multicolumn{2}{|c|}{ Stroke } & \multicolumn{2}{|c|}{ Skin Cancer } & \multicolumn{2}{|c|}{ Cancer } & \multicolumn{2}{|c|}{ COPD } & \multicolumn{2}{|c|}{ Arthritis } & \multicolumn{2}{|c|}{$\begin{array}{l}\text { Kidney } \\
\text { Disease }\end{array}$} \\
\hline & $\begin{array}{l}\text { Non- } \\
\text { Vet }\end{array}$ & Vet & $\begin{array}{l}\text { Non- } \\
\text { Vet }\end{array}$ & Vet & $\begin{array}{l}\text { Non- } \\
\text { Vet }\end{array}$ & Vet & $\begin{array}{l}\text { Non- } \\
\text { Vet }\end{array}$ & Vet & $\begin{array}{l}\text { Non- } \\
\text { Vet }\end{array}$ & Vet & $\begin{array}{l}\text { Non- } \\
\text { Vet }\end{array}$ & Vet & $\begin{array}{l}\text { Non- } \\
\text { Vet }\end{array}$ & Vet & $\begin{array}{l}\text { Non- } \\
\text { Vet }\end{array}$ & Vet & $\begin{array}{l}\text { Non- } \\
\text { Vet }\end{array}$ & Vet & $\begin{array}{l}\text { Non- } \\
\text { Vet }\end{array}$ & Vet \\
\hline Y2003 & 0.56 & 0.70 & 0.11 & 0.13 & 0.37 & 0.31 & $\mathrm{~N} / \mathrm{A}$ & $\mathrm{N} / \mathrm{A}$ & $\mathrm{N} / \mathrm{A}$ & $\mathrm{N} / \mathrm{A}$ & $\mathrm{N} / \mathrm{A}$ & $\mathrm{N} / \mathrm{A}$ & $\mathrm{N} / \mathrm{A}$ & $\mathrm{N} / \mathrm{A}$ & $\mathrm{N} / \mathrm{A}$ & $\mathrm{N} / \mathrm{A}$ & $\mathrm{N} / \mathrm{A}$ & $\mathrm{N} / \mathrm{A}$ & $\mathrm{N} / \mathrm{A}$ & $\mathrm{N} / \mathrm{A}$ \\
\hline Y2004 & 0.57 & 0.70 & 0.12 & 0.13 & 0.37 & 0.31 & $\mathrm{~N} / \mathrm{A}$ & $\mathrm{N} / \mathrm{A}$ & $\mathrm{N} / \mathrm{A}$ & $\mathrm{N} / \mathrm{A}$ & $\mathrm{N} / \mathrm{A}$ & $\mathrm{N} / \mathrm{A}$ & $\mathrm{N} / \mathrm{A}$ & $\mathrm{N} / \mathrm{A}$ & $\mathrm{N} / \mathrm{A}$ & $\mathrm{N} / \mathrm{A}$ & $\mathrm{N} / \mathrm{A}$ & $\mathrm{N} / \mathrm{A}$ & $\mathrm{N} / \mathrm{A}$ & $\mathrm{N} / \mathrm{A}$ \\
\hline Y2005 & 0.58 & 0.70 & 0.13 & 0.14 & 0.36 & 0.30 & 0.08 & 0.13 & 0.05 & 0.06 & $\mathrm{~N} / \mathrm{A}$ & $\mathrm{N} / \mathrm{A}$ & $\mathrm{N} / \mathrm{A}$ & $\mathrm{N} / \mathrm{A}$ & $\mathrm{N} / \mathrm{A}$ & $\mathrm{N} / \mathrm{A}$ & $\mathrm{N} / \mathrm{A}$ & $\mathrm{N} / \mathrm{A}$ & $\mathrm{N} / \mathrm{A}$ & $\mathrm{N} / \mathrm{A}$ \\
\hline Y2006 & 0.58 & 0.71 & 0.13 & 0.15 & 0.37 & 0.30 & 0.08 & 0.14 & 0.05 & 0.06 & $\mathrm{~N} / \mathrm{A}$ & $\mathrm{N} / \mathrm{A}$ & $\mathrm{N} / \mathrm{A}$ & $\mathrm{N} / \mathrm{A}$ & $\mathrm{N} / \mathrm{A}$ & $\mathrm{N} / \mathrm{A}$ & $\mathrm{N} / \mathrm{A}$ & $\mathrm{N} / \mathrm{A}$ & $\mathrm{N} / \mathrm{A}$ & $\mathrm{N} / \mathrm{A}$ \\
\hline Y2007 & 0.59 & 0.72 & 0.14 & 0.16 & 0.36 & 0.28 & 0.08 & 0.13 & 0.05 & 0.06 & $\mathrm{~N} / \mathrm{A}$ & $\mathrm{N} / \mathrm{A}$ & $\mathrm{N} / \mathrm{A}$ & $\mathrm{N} / \mathrm{A}$ & $\mathrm{N} / \mathrm{A}$ & $\mathrm{N} / \mathrm{A}$ & $\mathrm{N} / \mathrm{A}$ & $\mathrm{N} / \mathrm{A}$ & $\mathrm{N} / \mathrm{A}$ & N/A \\
\hline Y2008 & 0.60 & 0.73 & 0.14 & 0.15 & 0.36 & 0.30 & 0.08 & 0.14 & 0.05 & 0.06 & $\mathrm{~N} / \mathrm{A}$ & $\mathrm{N} / \mathrm{A}$ & $\mathrm{N} / \mathrm{A}$ & $\mathrm{N} / \mathrm{A}$ & $\mathrm{N} / \mathrm{A}$ & $\mathrm{N} / \mathrm{A}$ & $\mathrm{N} / \mathrm{A}$ & $\mathrm{N} / \mathrm{A}$ & $\mathrm{N} / \mathrm{A}$ & $\mathrm{N} / \mathrm{A}$ \\
\hline Y2009 & 0.60 & 0.73 & 0.14 & 0.16 & 0.36 & 0.30 & 0.07 & 0.13 & 0.05 & 0.06 & $\mathrm{~N} / \mathrm{A}$ & $\mathrm{N} / \mathrm{A}$ & $\mathrm{N} / \mathrm{A}$ & $\mathrm{N} / \mathrm{A}$ & $\mathrm{N} / \mathrm{A}$ & $\mathrm{N} / \mathrm{A}$ & $\mathrm{N} / \mathrm{A}$ & N/A & $\mathrm{N} / \mathrm{A}$ & $\mathrm{N} / \mathrm{A}$ \\
\hline Y2010 & 0.61 & 0.73 & 0.14 & 0.16 & 0.36 & 0.30 & 0.08 & 0.14 & 0.05 & 0.06 & $\mathrm{~N} / \mathrm{A}$ & $\mathrm{N} / \mathrm{A}$ & $\mathrm{N} / \mathrm{A}$ & $\mathrm{N} / \mathrm{A}$ & $\mathrm{N} / \mathrm{A}$ & $\mathrm{N} / \mathrm{A}$ & $\mathrm{N} / \mathrm{A}$ & N/A & $\mathrm{N} / \mathrm{A}$ & $\mathrm{N} / \mathrm{A}$ \\
\hline Y2011 & 0.60 & 0.73 & 0.15 & 0.18 & 0.37 & 0.30 & 0.08 & 0.13 & 0.05 & 0.06 & 0.11 & 0.16 & 0.11 & 0.13 & 0.08 & 0.09 & 0.37 & 0.36 & 0.03 & 0.03 \\
\hline Y2012 & 0.60 & 0.72 & 0.15 & 0.18 & 0.37 & 0.30 & 0.08 & 0.13 & 0.05 & 0.06 & 0.11 & 0.16 & 0.11 & 0.12 & 0.08 & 0.09 & 0.38 & 0.38 & 0.04 & 0.04 \\
\hline Y2013 & 0.60 & 0.72 & 0.16 & 0.18 & 0.35 & 0.29 & 0.08 & 0.13 & 0.05 & 0.06 & 0.11 & 0.16 & 0.11 & 0.16 & 0.08 & 0.10 & 0.38 & 0.37 & 0.04 & 0.04 \\
\hline Y2014 & 0.59 & 0.72 & 0.16 & 0.18 & 0.35 & 0.29 & 0.08 & 0.13 & 0.05 & 0.06 & 0.11 & 0.17 & 0.11 & 0.12 & 0.09 & 0.10 & 0.39 & 0.37 & 0.04 & 0.04 \\
\hline Y2016 & 0.59 & 0.71 & 0.17 & 0.19 & 0.36 & 0.30 & 0.08 & 0.12 & 0.05 & 0.06 & 0.11 & 0.16 & 0.11 & 0.13 & 0.08 & 0.10 & 0.38 & 0.38 & 0.04 & 0.05 \\
\hline Y2017 & 0.59 & 0.71 & 0.17 & 0.19 & 0.38 & 0.31 & 0.07 & 0.12 & 0.05 & 0.06 & 0.12 & 0.17 & 0.12 & 0.14 & 0.09 & 0.11 & 0.37 & 0.37 & 0.04 & 0.05 \\
\hline Y2018 & 0.60 & 0.72 & 0.17 & 0.20 & 0.39 & 0.32 & 0.07 & 0.12 & 0.05 & 0.07 & 0.12 & 0.17 & 0.12 & 0.14 & 0.09 & 0.11 & 0.38 & 0.39 & 0.05 & 0.05 \\
\hline Y2019 & 0.60 & 0.71 & 0.17 & 0.19 & 0.41 & 0.35 & 0.07 & 0.11 & 0.05 & 0.07 & 0.12 & 0.18 & 0.12 & 0.14 & 0.09 & 0.11 & 0.37 & 0.37 & 0.05 & 0.05 \\
\hline $\begin{array}{l}\text { Y11- } \\
\text { Y19 }\end{array}$ & 0.60 & 0.72 & 0.16 & 0.19 & 0.37 & 0.30 & 0.08 & 0.13 & 0.05 & 0.06 & 0.11 & 0.16 & 0.11 & 0.13 & 0.09 & 0.10 & 0.38 & 0.37 & 0.04 & 0.04 \\
\hline
\end{tabular}

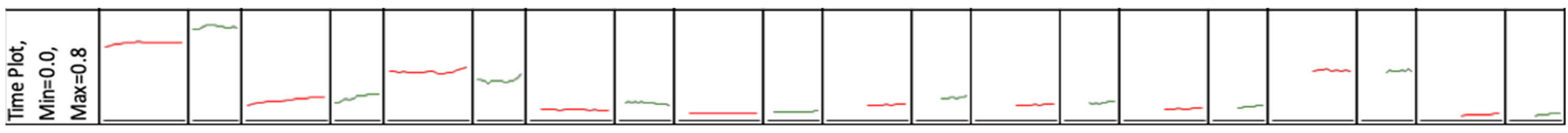

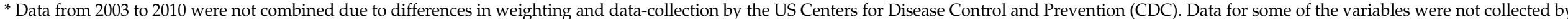
the CDC until 2011. 
Table 6. Age-adjusted comparisons for all dependent variables for years 2011-2019 by Veteran and non-Veteran status.

\begin{tabular}{|c|c|c|c|c|c|c|c|c|c|c|}
\hline Variable & Overweight/Obese & Heart Disease & Stroke & Skin Cancer & Cancer & COPD & Arthritis & $\begin{array}{l}\text { Mental } \\
\text { Health }\end{array}$ & $\begin{array}{l}\text { Kidney } \\
\text { Disease }\end{array}$ & Diabetes \\
\hline (Intercept) & $0.478^{* * *}$ & $0.004^{* * *}$ & $0.007^{* * *}$ & $0.001^{* * *}$ & $0.009 * * *$ & $0.035^{* * *}$ & $0.055^{* * *}$ & $1.356^{* * *}$ & $0.012 * * *$ & $0.015^{* * *}$ \\
\hline 25 to 34 & $2.010^{* * *}$ & $2.074^{* * *}$ & $2.753^{* * *}$ & $1.504^{* * *}$ & $2.663^{* * *}$ & $1.834^{* * *}$ & $2.87^{* * *}$ & $0.915^{* * *}$ & $1.728^{* * *}$ & $2.402^{* * *}$ \\
\hline 35 to 44 & $2.827^{* * *}$ & $4.645^{* * *}$ & $5.724^{* * *}$ & $3.518^{* * *}$ & $4.340^{* * *}$ & $2.863^{* * *}$ & $6.354^{* * *}$ & $0.844^{* * *}$ & $2.765^{* * *}$ & $6.931^{* * *}$ \\
\hline 45 to 54 & $3.305^{* * *}$ & $11.432^{* * *}$ & $10.822^{* * *}$ & $8.587^{* * * *}$ & $7.742 * * *$ & $4.831^{* * *}$ & $13.269^{* * *}$ & $0.748^{* * *}$ & $4.158^{* * *}$ & $15.439^{* * *}$ \\
\hline 55 to 64 & $3.526^{* * *}$ & $21.610^{* * *}$ & $15.455^{* * *}$ & $15.812^{* * *}$ & $12.604^{* * *}$ & $6.285^{* * *}$ & $22.293^{* * *}$ & $0.587^{* * * *}$ & $5.744^{* * *}$ & $25.632^{* * *}$ \\
\hline 65 or older & $3.111^{* * *}$ & $32.13^{* * *}$ & $19.386^{* * *}$ & $33.477^{* * *}$ & $21.72 * * *$ & $5.484^{* * *}$ & $27.973^{* * *}$ & $0.283^{* * *}$ & $7.123^{* * *}$ & $30.954^{* * *}$ \\
\hline Caucasian & 0.960 *** & $1.128^{* * *}$ & $0.768^{* * *}$ & $6.149^{* * *}$ & $1.342^{* * *}$ & $1.291^{* * *}$ & $1.205^{* * *}$ & $1.235^{* * *}$ & $0.864^{* * *}$ & $0.596^{* * *}$ \\
\hline Male & $1.889^{* * *}$ & $1.676^{* * *}$ & $1.093^{* * *}$ & $1.058^{* * *}$ & $0.618^{* * *}$ & $0.816^{* * *}$ & $0.664^{* * *}$ & $0.648^{* * *}$ & $0.948^{* * *}$ & $1.212^{* * *}$ \\
\hline Married & $1.072^{* * *}$ & $0.877^{* * *}$ & $0.718^{* * *}$ & $1.086^{* * *}$ & $0.953^{* * *}$ & $0.643^{* * *}$ & $0.850^{* * *}$ & $0.677^{* * *}$ & $0.833^{* * *}$ & $0.943^{* * *}$ \\
\hline Income $\geq \$ 75 \mathrm{~K}$ & $1.044^{* * *}$ & $0.749^{* * *}$ & $0.579^{* * *}$ & $1.180^{* * *}$ & $0.953^{* * *}$ & $0.515^{* * *}$ & $0.794^{* * * *}$ & $0.836^{* * * *}$ & $0.759^{* * *}$ & $0.694^{* * *}$ \\
\hline College Graduate & $0.689^{* * *}$ & $0.739^{* * *}$ & $0.639^{* * *}$ & $1.249^{* * *}$ & $1.016^{+}$ & $0.473^{* * *}$ & $0.671^{* * *}$ & $0.949^{* * *}$ & $0.789^{* * *}$ & $0.661^{* * *}$ \\
\hline Employed for Wages & $1.186^{* * *}$ & $0.472^{* * *}$ & $0.351^{* * *}$ & $0.78^{* * *}$ & $0.651^{* * *}$ & $0.46^{* * *}$ & $0.613^{* * *}$ & $0.756^{* * *}$ & $0.473^{* * *}$ & $0.663^{* * *}$ \\
\hline East North Central & $1.076^{* * *}$ & $1.217^{* * *}$ & $1.283^{* * *}$ & $1.48^{* * *}$ & $1.037^{*}$ & $1.297^{* * *}$ & $1.157^{* * * *}$ & $0.882^{* * *}$ & 1.016 & $1.203^{* * *}$ \\
\hline East South Central & $0.817^{* * *}$ & 0.999 & $0.869^{* * *}$ & 0.977 & 0.986 & $0.887^{* * *}$ & $0.899^{* * *}$ & $0.928^{* * *}$ & $0.839^{* * *}$ & $0.934^{* * *}$ \\
\hline Mountain & $0.790^{* * *}$ & $0.890^{* * *}$ & $0.840^{* * *}$ & $1.062^{* * *}$ & $1.039^{* *}$ & $0.870^{* * *}$ & $0.894^{* * *}$ & $0.976^{* *}$ & $0.877^{* * *}$ & $0.892 * * *$ \\
\hline Pacific & $0.743^{* * *}$ & $0.843^{* * *}$ & $0.845^{* * *}$ & $1.417^{* * *}$ & 1.027 & $0.766^{* * *}$ & $0.790^{* * * *}$ & $1.035^{* * * *}$ & 0.968 & $0.883^{* * *}$ \\
\hline South Atlantic & $0.883^{* * *}$ & 1.022 & 1.027 & $1.562^{* * *}$ & 0.996 & $1.022^{+}$ & $0.905^{* * *}$ & $0.853^{* * *}$ & 0.982 & 0.990 \\
\hline West North Central & 0.986 & $1.975^{* * *}$ & $0.597^{* * *}$ & $0.89 *$ & $0.902^{* *}$ & $0.785^{* * *}$ & 1.025 & $0.553^{* * *}$ & $0.745^{* * *}$ & 0.976 \\
\hline West South Central & $0.961^{* * *}$ & $0.913^{* * *}$ & 0.976 & $1.067^{* * *}$ & 0.998 & $0.849^{* * *}$ & $0.849^{* * *}$ & $0.808^{* * *}$ & $0.86^{* * *}$ & $0.935^{* * *}$ \\
\hline Territories of U.S & $0.980^{+}$ & $1.052^{*}$ & $1.107^{* * *}$ & $1.306^{* * *}$ & 0.979 & $0.962 *$ & $0.873^{* * *}$ & $0.845^{* * *}$ & 1.044 & $1.08^{* * *}$ \\
\hline Veteran & $1.239^{* * *}$ & $1.34^{* * *}$ & $1.276^{* * *}$ & $1.302^{* * *}$ & $1.509^{* * *}$ & $1.355^{* * *}$ & $1.247^{* * *}$ & $0.972^{* *}$ & $1.152 * * *$ & $1.108^{* * *}$ \\
\hline Year 2012 & 1.009 & $1.048^{* *}$ & 0.988 & $0.961^{* *}$ & 0.976 & $1.029^{+}$ & $1.069^{* * *}$ & 1.011 & $1.061^{*}$ & $1.04^{* *}$ \\
\hline Year 2013 & 1.006 & $0.956^{*}$ & 0.998 & 0.999 & 1.006 & $1.049^{* *}$ & $1.022 *$ & $0.939^{* * *}$ & $1.047^{+}$ & $1.04 * *$ \\
\hline Year 2014 & $0.974^{* *}$ & 0.992 & $1.045^{*}$ & 0.979 & $0.974^{+}$ & $1.069^{* * *}$ & $1.054^{* * *}$ & $0.941^{* * *}$ & $1.093^{* * *}$ & $1.066^{* * *}$ \\
\hline Year 2015 & $0.956^{* * *}$ & $0.904^{* * *}$ & 1.029 & 1.000 & 1.003 & 1.019 & 0.988 & $0.97^{* *}$ & $1.054^{*}$ & $1.055^{* * *}$ \\
\hline Year 2016 & $0.960 * * *$ & $0.965^{*}$ & $1.076^{* *}$ & 0.990 & 0.988 & $1.067^{* * *}$ & $1.034^{* * *}$ & $0.982 *$ & $1.163^{* * *}$ & $1.088^{* * *}$ \\
\hline Year 2017 & $0.982 *$ & $0.89^{* * *}$ & $1.087^{* * *}$ & 0.989 & 1.018 & $1.076^{* * *}$ & $0.972^{* *}$ & $1.043^{* * *}$ & $1.243^{* * *}$ & $1.102^{* * *}$ \\
\hline Year 2018 & 1.000 & 0.958 * & $1.156^{* * *}$ & 1.013 & 1.020 & $1.142^{* * *}$ & $1.056^{* * * *}$ & $1.076^{* * * *}$ & $1.224^{* * *}$ & $1.165^{* * *}$ \\
\hline
\end{tabular}




\section{Discussion}

Observing data over time, these results show that Veterans have disproportionately higher self-reported rates of stroke, skin cancer, cancer, COPD, arthritis, kidney disease, and diabetes. Similar to previous studies [1-5] these results appear to indicate Veteran populations are significantly less healthy than non-Veterans. Obesity was separated from the other variables as it was significantly higher for Veterans and may also contribute to the increased observance of the other morbidities [4].

Multiple deployments over the last several decades may be a major contributor to increased illness seen after separation from the service [38]. The demand placed upon the U.S. Service member, particularly since the mid to late 1980s has been illustrated in the number of military operations requiring deployment [20]. Unfortunately, the number of available personnel to support these deployments has not kept pace, resulting in more Service members deploying more often. As depicted in the health outcomes data, this combination of increased demand in military operations placed upon a smaller population may be resulting in a group of at-risk individuals for a variety of debilitating health conditions [1]. This study sought to utilize the BRFSS data to provide a snapshot or "glimpse" into a possible correlation between the stressors associated with multiple deployments, and poor health outcomes. Unfortunately, although the BRFSS dataset does illustrate those who identify themselves as 'Veterans,' it lacks the desired level of detail to fully define an association between multiple deployments and poor health outcomes. We hope that this study may prompt the Veterans Administration or similar responsible agencies to further refine the information collected on the Veteran population.

Additional stressors may exist in the occupational requirement for all Service members to meet stringent height and weight standards, and physical fitness standards, both of which are evaluated every six months [17]. Perhaps the combination of each of these stressors ultimately contribute to the stark differences in health outcomes between the Veteran populations compared to non-Veteran populations [1-3]. It is important to also note that self-reported mental health disorders and heart disease were not higher for Veterans when comparing to non-Veterans. It is possible that the negative consequences of reporting mental health issues in the military (e.g., security clearance revocation) continue to play a role in how persons reported in this dataset [39]. This phenomenon may also be a result of insufficient assessment for depression among the Veteran population by responsible agencies. Regardless, Veteran services to address the need for mental health services such as screening, assessment, and treatments continue to challenge the Veteran's Administration (VA) and the population they serve. The need for mental health services for Veterans continues to spawn new, innovative services from the VA such as the use of "tele-mental health" capabilities [40]. In fact, the advent of the current, worldwide COVID-19 pandemic has served as a catalyst to promoting and utilizing such tele-mental health services by Veterans [40]. The lower reports of heart disease may be due in part to the exercise regimen that Veterans experience while in the military. Further, we note that the jump from 2003 to 2007 in heart disease proportion may be due to increased diagnoses by the clinical community [41]. Further research in the area is needed.

As shown in our results, demographics and socio-economic variables could account partially for socioeconomic determinants of health associated with disease processes.

As such some specific health screening, prevention, and health care services should be provided to specific population based on our findings. Regarding the demographic, socioeconomic and geographic variables, our findings suggest that odds of being overweight, being diagnosed with a heart disease, skin cancer, or other cancers, COPD, arthritis, kidney disease and diabetes, as well as the odds of having a stroke increase with age. Walker et al., 2019, also found that weight and age were positively associated with the odds of having a heart disease [42]. In addition, being a Caucasian is associated with increased odds of having a heart disease, skin cancer, other cancers, arthritis, COPD, and mental health issues, but associated with lower odds of being overweight, having a stroke, or a kidney disease compared with being a non-Caucasian. Hispanics have a better health 
status than their non-Hispanic counterparts. While Hispanics have higher odds of being overweight, having a skin cancer, and a kidney disease, they have lower odds of having a heart disease, stroke, other cancers, COPD, arthritis, or mental health issue compared with non-Hispanics. Our finding that Hispanics are less likely to have heart disease is supported by previous study on veterans [42].

Furthermore, compared to being a female, being a male is associated with higher odds of being overweight, as well as having a heart disease, stroke, skin cancer, and diabetes, but it is associated with lower odds of having other cancers, COPD, arthritis, mental health issues, and kidney disease. With regards to marital status and annual income, married individuals, and those with annual income of $\geq \$ 75,000$ have a better health status than singles and those who have lower income. They are less likely to have heart disease stroke, other cancers, COPD, arthritis, mental health issues, kidney disease, and diabetes, but more likely to be overweight and having skin cancer, compared with their single- and lower-income counterparts. In the same vein, being college graduates and employed for wages are associated with a better health status compared with those who are not collage graduate and are not employed for wages. Being a college graduate was associated with lower odds of all having these health issues except for skin cancer and being employed for wage was only associated with being overweight. Our findings regarding the associations between gender and heart disease as well as income and heart disease are supported by Walker et al., 2019 [42].

With respect to geographic location, individuals who live in the East North Central, Middle Atlantic, Mountain, Pacific, South Atlantic, West South Central regions, as well as in the Territories of U.S. are more likely to have skin cancer, while individuals who reside in the West North Central region are more likely to have a heart disease."

Previous studies have also illustrated differences in burden of diseases, injuries, and risk factors in the United States by state [43]. It is interesting to note here that healthcare is provided to all Active-duty Service members while in the Service; therefore, access should not be an issue for the Service member. However, given this, there are still health disparities among the US military population primarily due to differences in health literacy, higher stress, and working conditions between those of lower rank and those of higher rank [44]. Further research must explore the factors of military rank, time in service, number of deployments, level of health literacy, and any additional factors which may account for differences in health outcomes in a population which has the same level of healthcare access. Another potential area of future study is how the length of time that a Veteran has been out of the Service impacts the Veteran's overall health status. It may be plausible to conclude that being a Veteran shortly before the survey year compared to being a Veteran for several years before the survey year may also result in different health statuses. Additionally, geographical effects were considered as they may account for culture and other locality factors (environmental effects). We saw in our results how geographies and physical locations vary and result in different health outcomes. Again, more research is needed in this area to further inform agencies such as the VA as to where to target resources that can meet the health needs of Veteran populations suffering from poorer health.

The data for 2019 indicate that Veteran status is associated with significantly different odds for all morbidities except for mental health disorders and kidney disease. When all other socio-economic and geographical variables are taken into consideration, Veterans in 2019 are estimated to have higher rates of morbidity for obesity / overweight status, heart disease (despite the time series graphs and after accounting for other variables), stroke, skin cancer, cancer, COPD (with an impressive odds ratio of 1.461), arthritis, and diabetes. These results may indicate, again, that the multiple deployments our military personnel have experienced over the last decade have had a significant impact on their overall health once separated from the military $[1,38]$. 


\section{Strengths and Limitations}

This study is the first to examine the various self-reported comorbidities among Veterans using the BRFSS dataset simultaneously with a robust statistical methodology. However, there are limitations. First, the BRFSS is cross-sectional, thus, odds ratios only provide the prevalence of each morbidity for that specific time period. Moreover, as illustrated in Table 2, the reporting of the morbidities was introduced at various years. Given the reliance of BRFSS of self-reporting, there is no feasible way to confirm the Veteran status for the respondents nor their medical diagnosis [45]. Furthermore, due to data limitation, this study was not able to include variables associated with military services, such as military rank, the number of deployments, the length of time in service, branch of service, the type of combat or exposure, the length of time between deployment and survey year, the number of injuries, the types of injuries, and the combat geographic locations. Future studies that include these variables should be considered. Finally, although there is complex weighting to account for sampling bias, there may still be issues related to coverage, selection bias, and an unrepresentative sample given that individuals within the Veteran population might be homeless and not included in the BRFSS (i.e., no cell phone or landline to be able to participate in the survey) [46].

\section{Conclusions}

The findings highlighted in this study paint a very concerning picture of the collective poor health of the US. Veteran. Our study findings suggest that when taken as a whole, these morbidities among Veterans could prompt the U.S. Department of Veteran Affairs (VA) to re-evaluate certain disabilities that the VA presumes were caused by military service (presumptive Service connection), as well as the impact of Veterans having multiple co-morbidities. Future studies should examine the interaction of multiple comorbidities on health outcomes of this population. Additionally, future studies should focus on possible reasons for the low occurrence of self-reported mental health disorders among those who served in the military. The findings in this study suggest a possible reluctance among Veterans to report these disorders and future studies should inquire as to potential causes. The study findings may also indicate an insufficient level of assessment among the Veteran population that accurately captures the true level of mental health challenges such as depression. Agencies such as the VA may potentially utilize these findings to develop and implement improved mental health assessment tools and procedures to better serve the Veteran population. Future studies should also seek to clarify the disproportionate impact and worsening health morbidities across targeted time periods for the Veteran group, either by stratifying our analysis or by generating a separate measure for multiple deployments and/or additional stressors as well as additional occupational requirement. Agencies such as the VA can use the findings of this study to better target scarce resources to geographies where there may be clusters of Veterans residing. The Veterans Health Administration (VHA), which is responsible for running the health system providing for the health needs of Veterans, may already be feeling the economic and resource impacts as a result of having an unhealthy Veteran population. However, additional research is needed using data sets that may contain more information that is specifically focused on the Veteran population. Such data may reside in certain organizations that cater to the needs of Veterans such as the American Legion, Veterans of Foreign Wars (VFW), or the Military Officers Association of America (MOAA).

Future studies might also examine the geographic locations where Veteran populations in the U.S. congregate [24]. These findings could assist the VA to design improved health intervention programs which could provide the necessary support to target populations. Additionally, this information could inform governmental and not-for-profit Veteranserving institutions on the magnitude of the overall health needs of the Veteran population and help develop more effective health interventions aimed at improving the overall health of the Veteran. By resourcing these organizations, community interventions can be built to 
improve the health of the U.S. Veteran population: a population who sacrificed much in service to their country.

Author Contributions: Conceptualization, J.A.B. and J.R.; Data curation, R.S. and L.V.F.; Formal analysis, P.S.G., G.J.P. and L.V.F.; Funding acquisition, R.S.; Investigation, G.J.P. and J.B.T.; Methodology, R.S. and L.V.F.; Project administration, J.A.B.; Resources, P.S.G. and J.B.T.; Supervision, J.A.B.; Validation, J.A.B. and P.S.G.; Writing—original draft, J.A.B. and J.B.T.; Writing—review \& editing, J.A.B., P.S.G., G.J.P., J.R., R.S., B.M.B., Z.H.R. and L.V.F. All authors have read and agreed to the published version of the manuscript.

Funding: The authors have received no external funding for the conduct of this analyses nor production of this manuscript.

Conflicts of Interest: All authors declare they have no conflicts of interest.

\section{References}

1. Betancourt, J.A.; Stigler Granados, P.; Pacheco, G.J.; Shanmugam, R.; Kruse, C.S.; Fulton, L.V. Obesity and Morbidity Risk in the U.S. Veteran. Healthcare 2020, 8, 191. [CrossRef]

2. Breland, J.Y.; Phibbs, C.S.; Hoggatt, K.J.; Washington, D.L.; Lee, J.; Haskell, S.; Uchendu, U.S.; Saechao, F.S.; Zephyrin, L.C.; Frayne, S.M. The Obesity Epidemic in the Veterans Health Administration: Prevalence Among Key Populations of Women and Men Veterans. J. Gen. Intern. Med. 2017, 32 (Suppl. 1), 11-17. [CrossRef]

3. Stefanovics, E.A.; Potenza, M.N.; Pietrzak, R.H. The physical and mental health burden of obesity in U.S. veterans: Results from the National Health and Resilience in Veterans Study. J. Psychiatr. Res. 2018, 103, 112-119. [CrossRef]

4. Reyes-Guzman, C.M.; Bray, R.M.; Forman-Hoffman, V.L.; Williams, J. Overweight and obesity trends among active duty military personnel: A 13-year perspective. Am. J. Prev. Med. 2015, 48, 145-153. [CrossRef] [PubMed]

5. Rush, T.; LeardMann, C.A.; Crum-Cianflone, N.F. Obesity and associated adverse health outcomes among US military members and veterans: Findings from the millennium cohort study. Obesity (Silver Spring) 2016, 24, 1582-1589. [CrossRef] [PubMed]

6. Wischik, D.L.; Magny-Normilus, C.; Whittemore, R. Risk Factors of Obesity in Veterans of Recent Conflicts: Need for Diabetes Prevention. Curr. Diabetes Rep. 2019, 19. [CrossRef] [PubMed]

7. Fryar, C.D.; Herrick, K.; Afful, J.; Ogden, C.L. Cardiovascular Disease Risk Factors Among Male Veterans, U.S., 2009-2012. Am. J. Prev. Med. 2016, 50, 101-105. [CrossRef] [PubMed]

8. Blanchard, M.S.; Eisen, S.A.; Alpern, R.; Karlinsky, J.; Toomey, R.; Reda, D.J.; Murphy, F.M.; Jackson, L.W.; Kang, H.K. Chronic multisymptom illness complex in Gulf War I veterans 10 years later. Am. J. Epidemiol. 2006, 163, 66-75. [CrossRef] [PubMed]

9. Buschemeyer, W.C., III; Freedland, S.J. Obesity and Prostate Cancer: Epidemiology and Clinical Implications. Eur. Urol. 2007, 52, 331-343. [CrossRef] [PubMed]

10. Lavie, C.J.; De Schutter, A.; Parto, P.; Jahangir, E.; Kokkinos, P.; Ortega, F.B.; Arena, R.; Milani, R.V. Obesity and Prevalence of Cardiovascular Diseases and Prognosis-The Obesity Paradox Updated. Prog. Cardiovasc. Dis. 2016, 58, 537-547. [CrossRef]

11. Stefanovics, E.A.; Potenza, M.N.; Pietrzak, R.H. Smoking, obesity, and their co-occurrence in the U.S. military veterans: Results from the national health and resilience in veterans study. J. Affect. Disord. 2020, 274, 354-362. [CrossRef]

12. Tamas, M.J.; Khakharia, A.; Rothenberg, R.B.; Phillips, L.S. Weight Trends in Veterans with and without Diabetes, 2000 to 2014. Obesity (Silver Spring) 2018, 26, 1949-1957. [CrossRef]

13. Tanofsky-Kraff, M.; Sbrocco, T.; Theim, K.R.; Cohen, L.A.; Mackey, E.R.; Stice, E.; Henderson, J.L.; McCreight, S.J.; Bryant, E.J.; Stephens, M.B. Obesity and the US military family. Obesity (Silver Spring) 2013, 21, 2205-2220. [CrossRef] [PubMed]

14. Maguen, S.; Hoerster, K.D.; Littman, A.J.; Klingaman, E.A.; Evans-Hudnall, G.; Holleman, R.; Kim, H.M.; Goodrich, D.E. Iraq and Afghanistan veterans with PTSD participate less in VA's weight loss program than those without PTSD. J. Affect. Disord. 2016, 193, 289-294. [CrossRef]

15. Jay, M.; Mateo, K.F.; Squires, A.P.; Kalet, A.L.; Sherman, S.E. Military service and other socioecological factors influencing weight and health behavior change in overweight and obese Veterans: A qualitative study to inform intervention development within primary care at the United States Veterans Health Administration. BMC Obes. 2016, 3, 1.

16. Cesur, R.; Sabia, J.J.; Tekin, E. The psychological costs of war: Military combat and mental health. J. Health Econ. 2013, $32,51-65$. [CrossRef] [PubMed]

17. Masheb, R.M.; Kutz, A.M.; Marsh, A.G.; Min, K.M.; Ruser, C.B.; Dorflinger, L.M. "Making weight" during military service is related to binge eating and eating pathology for veterans later in life. Eat. Weight Disord 2019, 24, 1063-1070. [CrossRef]

18. United States Department of Defense Manpower Data Center. Selected Manpower Statistics. Available online: http://web1.whs. osd.mil/mmid/mmidhome.htm (accessed on 30 December 2020).

19. Kane, T. Total Volunteer Force: Lessons from the US Military on Leadership Culture and Talent Management; Hoover Institution Press: Stanford, CA, USA, 2017.

20. Doubleday, J. Review may examine increased deployments: Pentagon advisers to study logic behind use of reserve components. Inside Army 2014, 26, 1-6. 
21. Adams, M.L.; Grandpre, J.; Katz, D.L.; Shenson, D. Linear association between number of modifiable risk factors and multiple chronic conditions: Results from the Behavioral Risk Factor Surveillance System. Prev. Med. 2017, 105, 169-175. [CrossRef] [PubMed]

22. Adams, M.L.; Grandpre, J.; Katz, D.L.; Shenson, D. The impact of key modifiable risk factors on leading chronic conditions. Prev. Med. 2019, 120, 113-118. [CrossRef] [PubMed]

23. Stone, C.L. A population-based measure of chronic disease severity for health planning and evaluation in the United States. AIMS Public Health 2020, 7, 44-65. [CrossRef]

24. US Centers for Disease Control and Prevention. Behavioral Health Risk Factor Surveillance System (BRFSS) 2011 Survey Data and Documentation. 2013. Available online: https://www.cdc.gov/brfss/annual_data/annual_2011.htm (accessed on 30 December 2020).

25. US Centers for Disease Control and Prevention. Behavioral Risk Factor Surveillance System (BRFSS) Historical Questions. 2019. Available online: https: / healthdata.gov / dataset/behavioral-risk-factor-surveillance-system-brfss-historical-questions\#: \{\}: text=BRFSS\%20Survey\%20Data.,cdc.gov\%2Fbrfss (accessed on 30 December 2020).

26. U.S. Centers for Disease Control and Prevention. Survey Data \& Documentation. Available online: https://www.cdc.gov/brfss/ data_documentation/index.htm (accessed on 30 December 2020).

27. R Core Team. R: A Language and Environment for Statistical Computing; R Foundation for Statistical Computing: Vienna, Austria, 2018; Available online: https:/ / www.R-project.org/ (accessed on 30 December 2020).

28. U.S. Centers for Disease Control and Prevention. Behavioral Risk Factor Surveillance System. 2020. Available online: https: //www.cdc.gov/brfss/annual_data/annual_data.htm (accessed on 30 December 2020).

29. U.S. Centers for Disease Control and Prevention. Behavioral Risk Factor Surveillance System (BRFSS). Available online: https: //www.cdc.gov / brfss/index.html (accessed on 28 December 2020).

30. Fulton, L.V. BRFSS. Available online: https://rpubs.com/R-Minator/BRFSS (accessed on 30 December 2020).

31. Tufte, E.R. The Visual Display of Quantitative Information; Graphics Press: Chesire, CT, USA, 2001; p. 170.

32. US Bureau of the Census. Map of the United States, Showing Census Divisions and Regions. 1995. Available online: https: //www.census.gov/prod/1/gen/95statab/preface.pdf (accessed on 30 December 2020).

33. RStudio. RStudio: Integrated Development Environment for R. Available online: http://www.rstudio.com/ (accessed on 7 November 2020).

34. Lumley, T. Analysis of Complex Survey Samples. J. Stat. Softw. 2004, 1. [CrossRef]

35. Aragon, T.J. Epitools: Epidemiology Tools. R Package Version 0.5-10.1. 2020. Available online: https:/ /CRAN.R-project.org/ package=epitools (accessed on 12 September 2020).

36. Lumley, T. Complex Survey Samples in R. Available online: https:/ / faculty.washington.edu/tlumley/old-survey/survey-wss.pdf (accessed on 30 December 2020).

37. Fox, J.; Weisberg, S. Visualizing fit and lack of fit in complex regression models with predictor effect plots and partial residuals. J. Stat. Softw. 2018, 87, 1-27. [CrossRef]

38. Interian, A.; Kline, A.; Janal, M.; Glynn, S.; Losonczy, M. Multiple deployments and combat trauma: Do homefront stressors increase the risk for posttraumatic stress symptoms? J. Trauma Stress 2014, 27, 90-97. [CrossRef] [PubMed]

39. Acosta, J.D. Mental Health Stigma in the Military; RAND: Santa Monica, CA, USA, 2014; p. xxxii. 296p.

40. Connolly, S.L.; Stolzmann, K.L.; Heyworth, L.; Weaver, K.R.; Bauer, M.S.; Miller, C.J. Rapid Increase in Telemental Health within the Department of Veterans Affairs During the COVID-19 Pandemic. Telemed. J. e Health. [CrossRef]

41. Williams, R.G. Increased Survival of Congenital Heart Disease: How Did We Get Here and Now What? J. Am. Coll. Cardiol. 2015, 66, 45-46. [CrossRef] [PubMed]

42. Walker, L.E.; Poltavskiy, E.; Janak, J.C.; Beyer, C.A.; Stewart, I.J.; Howard, J.T. US Military Service and Racial/Ethnic Differences in Cardiovascular Disease: An Analysis of the 2011-2016 Behavioral Risk Factor Surveillance System. Ethn. Dis. 2019, 29 , 451-462. [CrossRef] [PubMed]

43. The US Burden of Disease Collaborators; Mokdad, A.H.; Ballestros, K.; Echko, M.; Glenn, S.; Olsen, H.E.; Mullany, E.; Lee, A.; Khan, A.R.; Ahmadi, A.; et al. The State of US Health, 1990-2016: Burden of Diseases, Injuries, and Risk Factors Among US States. JAMA 2018, 319, 1444-1472. [CrossRef]

44. Blattner, M.; Price, J.; Holtkamp, M.D. Socioeconomic class and universal healthcare: Analysis of stroke cost and outcomes in US military healthcare. J. Neurol. Sci. 2018, 386, 64-68. [CrossRef]

45. Luncheon, C.; Zack, M. Health-related quality of life among US veterans and civilians by race and ethnicity. Prev. Chronic. Dis. 2012, 9, E108. [CrossRef] [PubMed]

46. U.S. Centers for Disease Control and Prevention. BRFSS Today: Facts and Highlights. 2014. Available online: https://www.cdc. gov/brfss/about/brfss_today.htm (accessed on 29 December 2020). 